\title{
Yield of Wheat (Triticum aestivum) and Nutrient Uptake in Grain and Straw as Influenced by Some Macro (S \& Mg) and Micro (B \& Zn) Nutrients
}

Md. Abul Kalam Azad1, Tazuddin Ahmed1', Touria El-Jaoual Eaton², Md. Mukhtar Hossain'1, Md. Kamrul Haque ${ }^{1}$, Edward Binod Soren ${ }^{1}$

${ }^{1}$ Department of Crop Science \& Technology, Rajshahi University, Rajshahi, Bangladesh; ${ }^{2}$ Cooperative Extension and Research, Lincoln University of Missouri, Jefferson, MO, USA

Correspondence to: Md. Abul Kalam Azad, azad.adrinwa@gmail.com

Keywords: Grain, Straw, Treatments, Nutrient Content, Nutrient Uptake, Wheat Yield

Received: August 2, $2021 \quad$ Accepted: August 31, $2021 \quad$ Published: September 3, 2021

Copyright (c) 2021 by author(s) and Scientific Research Publishing Inc.

This work is licensed under the Creative Commons Attribution-NonCommercial International License (CC BY-NC 4.0).

http://creativecommons.org/licenses/by-nc/4.0/

\section{(c) (i) $\$$ Open Access}

\section{ABSTRACT}

A wheat variety BARI Gom 26 was cultivated with an objective of evaluating the effects of macro/secondary nutrients as $\mathrm{S}$ and $\mathrm{Mg}$, and micro nutrients as $\mathrm{B}$ and $\mathrm{Zn}$ on yield, yield contributing traits and nutrient uptake status by the crop. The field experiment was conducted in the "North Eastern Barind Tract Soils" at Kushadaha, Nawabganj, Dinajpur, Bangladesh from November, 2014 to March, 2015. The surface soil was clay in texture, having $\mathrm{pH} 5.61$, organic matter $1.58 \%$, total $\mathrm{N} 0.10 \%$, available $\mathrm{P} 7.03 \mathrm{ppm}$, exchangeable $\mathrm{K}$ $0.11 \mathrm{meq} / 100 \mathrm{~g}$, available S $2.57 \mathrm{ppm}$, exchangeable $\mathrm{Mg} 0.55 \mathrm{meq} / 100 \mathrm{~g}$, available $\mathrm{Zn} 1.30$ $\mathrm{ppm}$, available B $0.08 \mathrm{ppm}$. The experiment was designed with five treatments laid out in a randomized complete block design (RCBD) with three replications. The treatments were $\mathrm{T}_{1}$ : $\mathrm{NPK}$ (control), $\mathrm{T}_{2}: \mathrm{NPK}+\mathrm{S}, \mathrm{T}_{3}: \mathrm{NPK}+\mathrm{S}+\mathrm{Mg}, \mathrm{T}_{4}: \mathrm{NPK}+\mathrm{S}+\mathrm{Mg}+\mathrm{Zn}$ and $\mathrm{T}_{5}: \mathrm{NPK}+\mathrm{S}+$ $\mathrm{Mg}+\mathrm{Zn}+\mathrm{B}$. All plots of wheat received $100 \mathrm{~kg} \mathrm{~N} / \mathrm{ha}, 30 \mathrm{~kg} P / \mathrm{ha}$ and $70 \mathrm{~kg} \mathrm{~K} / \mathrm{ha}$ as basal dose. The secondary and micro nutrients doses were $15 \mathrm{~kg} \mathrm{~S} / \mathrm{ha}, 6 \mathrm{~kg} \mathrm{Mg} / \mathrm{ha}, 2.5 \mathrm{~kg} \mathrm{Zn} / \mathrm{ha}$ and $1.5 \mathrm{~kg} \mathrm{~B} / \mathrm{ha}$. Results revealed that the plant height, tillers/hill, 1000-grain weight, yield of grain and straw, uptake of some specific nutrients in grain and straw were significantly influenced by all the treatments, though these treatments did not show any identical effect on spike length, content of $\mathrm{P}$ and $\mathrm{Mg}$ in wheat. Significantly highest amount of 1000-grain weight, yield of grain and straw weight of wheat were obtained in applying $\mathrm{T}_{2}$ treatment that employed the addition of $S$ with recommended dose of NPK. Significant positive effects were also observed for the rest parameters in receiving the treatments composed of secondary and micronutrients $\left(T_{3}, T_{4}\right.$, and $\left.T_{5}\right)$. The highest concentration of nutrient uptake $N, P$, $\mathrm{K}$ and $\mathrm{S}$ in grain and straw of wheat were also obtained due to the application of $\mathrm{T}_{2}$ treat- 
ment. In the case of $\mathrm{Mg}$, the maximum uptake was recorded in $\mathrm{T}_{4}$ where $\mathrm{Mg}$ was added as a component of this treatment. In contrast, the highest content of $\mathrm{Zn}$ and B were extracted in receiving the treatment $T_{5}$ both for grain and straw. However, results suggested that $T_{2}$ treatment comprising recommended dose of NPK with S might be economic and suitable as for better production of 1000-grain weight, yield of grain and straw, uptake of N, P, K and S in grain and straw of wheat cultivated in the North Eastern Barind Tract Soils of Bangladesh under winter condition. The treatment $\mathrm{T}_{5}$ would also be recommended in the context of addition of micronutrients.

\section{INTRODUCTION}

Wheat (Triticum aestivum) is the second most important crop and about two-thirds of the world's population lives on wheat grains. It can be a good supplement of rice and can play a vital role to feed the teeming millions of hungry people in Bangladesh. It is superior to rice for its higher protein content, vitamins and minerals. The annual production of wheat grain in 2010-2011 in Bangladesh was 0.901 million metric tons obtained from 0.374 million hectare of land with an average yield of $970 \mathrm{~kg} / \mathrm{ac}$ [1]. The urgent need of the crop sector of Bangladesh Agriculture at this moment is to produce more food to feed the country's ever growing population. To attain self-sufficiency in food, efforts must be made to enhance the yield per unit area and improve the quality of the produce.

Soil fertility status gradually declining in the yield of major crops of the country is now becoming a very alarming issue for the scientists and policy makers [2]. The soils of Bangladesh are already depleted in many essential nutrients mainly because of intensive cultivation having no return from organic recycling. Inorganic fertilizers today hold the key to the success of the crop production systems of Bangladesh agriculture, being responsible for about 50\% of the total production [3]. Before 1980's deficiency of NPK was a major problem but thereafter NPK deficiency along with secondary and micro nutrients ( $\mathrm{S}$ and $\mathrm{Zn}$ ) was frequently reported $[4,5]$. Micronutrient deficiency is widespread in many Asian countries due to the high $\mathrm{pH}$, low organic matter, salt stress, continuous drought, high bicarbonate content in irrigation water, and imbalanced application of NPK (the amount of nitrogen, phosphorus, and potassium in a fertilizer) fertilizers [6]. Sulphur deficiency has been recognized in many areas of Bangladesh, which roughly covers $44 \%$ of the total cropped area [7]. Magnesium also plays an eminent role in the growth and development of plants [8]. According to Li et al. [8], both zinc and magnesium are highly effective in increasing the quantity and quality of wheat grain yield. Boron deficiency was also reported on some soils and crops [9-11]. Consequently, $\mathrm{Zn}$ and B deficiency were frequently reported on some soils and crops in different areas of Bangladesh $[9,12]$.

Proper soil fertility management, therefore, is of prime importance in an endeavor to increase crop productivity. The farmers of Bangladesh are very poor and illiterate. They don't know the proper use of secondary and micro nutrients. The emergence of secondary and micronutrient deficiency can be mitigated with inorganic fertilizers. Moreover, the combined use of organic and inorganic fertilizers might be helpful for proper sustainable crop production and maintenance of soil fertility. Considering the above points in view, the experiment was conducted to investigate the effect of $\mathrm{S}$ and $\mathrm{Mg}$ from secondary nutrients and $\mathrm{B}$ and $\mathrm{Zn}$ under micronutrients on the yield and yield contributing characters of wheat along with the nutrient uptake in grain and straw determining the effective doses of fertilizers containing these elements cultivating BARI Gom 26 at North Eastern Barind Tract of Bangladesh.

\section{MATERIALS AND METHODS}

\subsection{Locale and Characteristics of Experimental Soil}

The experiment was carried out at Kushdaha, Nawabgonj under Dinajpur district in Bangladesh with the geographical position of the area is between $25^{\circ} 62^{\prime} \mathrm{N}, 88^{\circ} 63^{\prime} \mathrm{E}$ and 38.20 meters above sea level. The 
selected modern high yielding variety of wheat "BARI Gom 26" was developed by Bangladesh Agricultural Research Institute (BARI), Gazipur and was cultivated with some treatments during the Rabi season from $12^{\text {th }}$ November, 2014 to $27^{\text {th }}$ March, 2015 in the experimental plots. The climate of the experimental area is characterized by high temperature accompanied by moderately maximum rainfall during low temperature in the Rabi season (October to March). In Rabi season temperature is generally low and there is plenty of sunshine.

The soil belongs to Noadda soil series representing the Shallow Red Brown Terrace, medium high land, leveled topography, and moderate drainage system under North Eastern Barind Tract [13]. The textural class of experimental plot soil was clay and the consisting of soil particles were sand, silt, clay $17 \%$, $39 \%$ and $44 \%$ accordingly, having $\mathrm{pH} 5.61$, organic matter $1.58 \%$, total $\mathrm{N} 0.10 \%$, available $\mathrm{P} 7.03 \mathrm{ppm}$, exchangeable K $0.11 \mathrm{meq} / 100 \mathrm{~g}$, available S $2.57 \mathrm{ppm}$, exchangeable Mg $0.55 \mathrm{meq} / 100 \mathrm{~g}$, available Zn 1.30 ppm, available B 0.08 ppm, available Fe 107.60 ppm and available Mn 88.47 ppm.

\subsection{Design, Treatments and Agronomic Management}

The experiment was laid out in a randomized complete block design (RCBD) with three replications. The total numbers of plots were 15 . The unit plot size was $4 \mathrm{~m} \times 3 \mathrm{~m}$. The distance between two unit plots was $0.3 \mathrm{~m}$ and between blocks $0.7 \mathrm{~m}$. The treatments were randomized to the plots in each block. There were five treatment combinations given below consisting of $\mathrm{S}, \mathrm{Mg}, \mathrm{Zn}$ and $\mathrm{B}$ including one control (receiving N, P and $\mathrm{K}) ; \mathrm{T}_{1}=\mathrm{NPK}$ (Control); $\mathrm{T}_{2}=\mathrm{N} \mathrm{P} \mathrm{K}+\mathrm{S} ; \mathrm{T}_{3}=\mathrm{N} \mathrm{P} \mathrm{K}+\mathrm{S}+\mathrm{Mg} ; \mathrm{T}_{4}=\mathrm{N} \mathrm{P} \mathrm{K}+\mathrm{S}+\mathrm{Mg}+\mathrm{Zn}$; $\mathrm{T}_{5}=\mathrm{N} \mathrm{P} \mathrm{K}+\mathrm{S}+\mathrm{Mg}+\mathrm{Zn}+\mathrm{B}$.

All the treatments contained recommended doses of N, P, K, S, Mg, Zn and B but sources were different. All plots of wheat received $100 \mathrm{~kg} \mathrm{~N} / \mathrm{ha}, 30 \mathrm{~kg} \mathrm{P} / \mathrm{ha}$ and $70 \mathrm{~kg} \mathrm{~K} / \mathrm{ha}$ from urea, TSP and MP respectively as basal dose, and the doses of secondary and micro nutrients were $15 \mathrm{~kg} \mathrm{~S} / \mathrm{ha}, 6 \mathrm{~kg} \mathrm{Mg} / \mathrm{ha}, 2.5 \mathrm{~kg}$ $\mathrm{Zn} / \mathrm{ha}$ and $1.5 \mathrm{~kg} \mathrm{~B} /$ ha from gypsum, magnesium oxide, zinc oxide and borax respectively.

Land preparation was started on November 04, 2014 for cultivation of wheat. The full dose of triple super phosphate (TSP), muriate of potash (MoP), gypsum, magnesium oxide, zinc oxide, borax and $1 / 3$ urea were applied at the time of final land preparation. The second split of urea after 30 days of sowing and third split after 55 days after sowing (booting stage) of wheat seeds were broadcasted. Wheat seeds (BARI Gom26) were sown on $12^{\text {th }}$ November 2014 at the rate of $120 \mathrm{~kg} / \mathrm{ha}$ sequentially at $20 \mathrm{~cm}$ apart between lines. Weeding and irrigation were done twice during the whole growth period, performed after 30 and 55 days after sowing. Top dressing of urea was done on the following day of irrigation. There was no infestation of insects, pests and diseases in the field, therefore, no control measures were required for insects, pests and diseases. All data on plant height $(\mathrm{cm})$, tillers/hill, spike length $(\mathrm{cm}), 1000$-seed weight $(\mathrm{g})$, grain yield $(\mathrm{kg} / \mathrm{ha})$, straw yield $(\mathrm{kg} / \mathrm{ha})$ were taken when the crop attained maturity. Harvesting of wheat crop was done on $27^{\text {th }}$ March 2015. The parameters plant height, spike length and 1000-grains weight (g) were collected from 10 (ten) randomly selected plants taken from each plot. Grain and straw yields were recorded plot-wise on sundry basis (12\% moisture basis). Grain and straw samples were collected, dried and ground for chemical analysis.

\subsection{Estimation of NPK, Secondary (S and Mg) and Micro Nutrients (B \& Zn) from Grain and Straw}

Plant samples of grain and straw were collected after the harvesting of wheat from the experimental field to analyze for N, P, K, S, Mg, Zn and B contents. Grain and straw samples were dried in an oven at about $65^{\circ} \mathrm{C}$ for 48 hours and then ground in a grinding mill to pass through a 20 mesh sieve. The ground plant materials (grain and straw) were stored in small paper bags and placed in desiccators for the next step to analyze.

\subsubsection{Digestion of Plant Samples with Sulphuric and Perchloric Acid in 2:1 Ratio for Nitrogen} (N) Estimation

Plant extract was prepared by digesting dried samples first with concentrated sulphuric acid and then 
perchloric acid for the determination of $\mathrm{N}$. An amount of $0.5 \mathrm{~g}$ oven-dried ground sample was taken in a $150 \mathrm{~mL}$ Kjeldahl flask $0.5 \mathrm{~mL}$ concentrated $\mathrm{H}_{2} \mathrm{SO}_{4}$ was added into the flask and the flask was allowed to stand for overnight. Then $2.5 \mathrm{~mL}$ perchloric acid was added into the flask. After leaving for a while, the flasks were heated and the temperature was raised slowly to $200^{\circ} \mathrm{C}$ heating was continued until the digest was clear and colorless. After cooling, the content was transferred into a $100 \mathrm{~mL}$ volumetric flask, and the volume was made up to the mark with distilled water. A reagent blank was prepared in a similar manner. This digestion was performed particularly for $\mathrm{N}$ determination. Nitrogen in the digest was estimated by distillation with $40 \% \mathrm{NaOH}$ followed by titration of the distillate trapped in $\mathrm{H}_{3} \mathrm{BO}_{3}$ with $0.01 \mathrm{~N} \mathrm{H}_{2} \mathrm{SO}_{4}$ [14].

\subsubsection{Digestion of Plant Samples with Nitric and Perchloric Acid in 2:1 Ratio for $\mathrm{P}, \mathrm{K}, \mathrm{S}, \mathrm{Mg}$, Zn and B Estimation}

Plant samples were digested by wet oxidation method with nitric-perchloric acid for the determination of phosphorus, potassium, sulphur, magnesium, zinc and boron. Sulphur in the digest was measured by the acid seed turbid metric procedure improved by [15].

An amount of $0.5 \mathrm{~g}$ oven-dry ground samples was taken in a $150 \mathrm{~mL}$ Kjeldahl flask. Concentrated nitric acid of $5 \mathrm{~mL}$ was added into the flask and the flask was allowed to stand for about 24 hours. Then 2.5 $\mathrm{mL}$ perchloric acid was added into the flask, followed by heating to boiling. Heating was continued until the digest was clear and colorless. After cooling, the content was transferred to a $50 \mathrm{~mL}$ volumetric flask and the volume was made up to the mark with distilled water. A reagent blank was prepared in the similar manner.

Except $\mathrm{N}$, all the elements ( $\mathrm{P}, \mathrm{K}, \mathrm{S}, \mathrm{Mg}, \mathrm{Zn}$ and $\mathrm{B}$ ) were determined from this single digest extract sample. The concentration of $\mathrm{P}$ in the acid digest was determined colorimetrically using molybdovanadate solution yellow colour method [16]. The K concentration in the extract was determined directly by flame photometer [16]. The $\mathrm{Mg}$ and $\mathrm{Zn}$ concentration was determined directly by atomic absorption spectrophotometer [16]. The $\mathrm{S}$ concentration in the acid digest was determined by turbidity method using $\mathrm{BaCl}_{2}$ [17]. Boron concentration of the extract was determined by the method of Azomethine-H [14] using spectrophotometer at $420 \mathrm{~nm}$.

\subsection{Statistical Analysis}

Collected data on grain yield and yield contributing characters, concentrations of $\mathrm{N}, \mathrm{P}, \mathrm{K}, \mathrm{Mg}, \mathrm{S}, \mathrm{Zn}$ and B uptake in grain and straw of wheat were analyzed statistically [18] by F-test to examine the treatments whether they had significant effects. The comparisons of the mean treatments were adjusted by the Duncan's Multiple Range Test (DMRT). The analyses of variance (ANOVA) for different treatment parameters were done by "MSTATC" a computer package programme.

\section{RESULTS AND DISCUSSION}

\subsection{Effect of Different Treatments on the Yield and Yield Components of Wheat}

Wheat production was significantly affected with the treatment combinations of secondary nutrients $\mathrm{S}$ and $\mathrm{Mg}$, and micronutrients $\mathrm{Zn}$ and $\mathrm{B}$ along with the recommended dose of NPK. The accumulated data on the yield components comprise plant height, tillers per hill, spike length, 1000-grain weight, grain and straw yield of wheat as affected by different treatments are presented in Table 1. Plant height and tillers per hill were obtained significantly greater as $94.03 \mathrm{~cm}$ and 3.36 respectively from $\mathrm{T}_{3}$ treatment in receiving $\mathrm{S}$ and $\mathrm{Mg}$ with NPK as basal dose which was similar with both the treatments $\mathrm{T}_{2}$ and $\mathrm{T}_{5}(93.80 \mathrm{~cm})$ followed by $\mathrm{T}_{4}(93.36 \mathrm{~cm})$ and the lowest was found in control $\mathrm{T}_{1}$ by using recommended dose of NPK.

The highest plant height and tillers per hill were obtained from the recommended dose of $(\mathrm{NPK}+\mathrm{S}+$ $\mathrm{Mg}$ ) or (NPK fertilizers $+\mathrm{S}+\mathrm{Mg}+\mathrm{B}+\mathrm{Zn}$ ) treated plot, which were supported by the findings of Hossain et al. [19]. Spike length of wheat is mainly controlled genetically and also influenced by environmental factors [20]. No statistical difference in spike length was noticed among all the treatments, in spite it $\mathrm{T}_{3}$ 
Table 1. Effect of different treatments on yield and yield components of wheat.

\begin{tabular}{ccccccc}
\hline Treatments & $\begin{array}{c}\text { Plant } \\
\text { height } \\
(\mathbf{c m})\end{array}$ & $\begin{array}{c}\text { Tillers/hill } \\
(\text { no. })\end{array}$ & $\begin{array}{c}\text { Spike } \\
\text { Length } \\
(\mathbf{c m})\end{array}$ & $\begin{array}{c}1000 \text { grain } \\
\text { weight }(\mathbf{g})\end{array}$ & $\begin{array}{c}\text { Grain } \\
\text { yield } \\
(\mathrm{Kg} / \mathrm{ha})\end{array}$ & $\begin{array}{c}\text { Straw } \\
\text { yield } \\
(\mathrm{Kg} / \mathrm{ha})\end{array}$ \\
\hline $\mathrm{T}_{1} \mathrm{NPK}$ (Control) & $92.73 \mathrm{c}$ & $2.99 \mathrm{~b}$ & $8.60 \mathrm{a}$ & $39.38 \mathrm{a}$ & $2650 \mathrm{e}$ & $3583 \mathrm{e}$ \\
$\mathrm{T}_{2} \mathrm{NPK}+\mathrm{S}$ & $93.80 \mathrm{bc}$ & $3.26 \mathrm{ab}$ & $8.96 \mathrm{a}$ & $43.08 \mathrm{~b}$ & $2992 \mathrm{~b}$ & $4342 \mathrm{~b}$ \\
$\mathrm{~T}_{3} \mathrm{NPK}+\mathrm{S}+\mathrm{Mg}$ & $94.03 \mathrm{bc}$ & $3.36 \mathrm{ab}$ & $9.13 \mathrm{a}$ & $39.51 \mathrm{a}$ & $2908 \mathrm{c}$ & $4092 \mathrm{c}$ \\
$\mathrm{T}_{4} \mathrm{NPK}+\mathrm{S}+\mathrm{Mg}+\mathrm{Zn}$ & $93.36 \mathrm{c}$ & $3.10 \mathrm{~b}$ & $8.70 \mathrm{a}$ & $40.85 \mathrm{a}$ & $2708 \mathrm{e}$ & $3750 \mathrm{~d}$ \\
$\mathrm{~T}_{5} \mathrm{NPK}+\mathrm{S}+\mathrm{Mg}+\mathrm{Zn}+\mathrm{B}$ & $93.80 \mathrm{bc}$ & $3.33 \mathrm{ab}$ & $9.10 \mathrm{a}$ & $39.64 \mathrm{a}$ & $2808 \mathrm{~d}$ & $4108 \mathrm{c}$ \\
$\mathrm{CV}(\%)$ & $\mathbf{5 . 7 5}$ & 3.95 & $\mathbf{4 . 0 3}$ & $\mathbf{4 . 0 7}$ & $\mathbf{4 . 2 2}$ & $\mathbf{1 . 5 7}$ \\
S. E. $\mathbf{( \pm )}$ & $\mathbf{0 . 8 5}$ & $\mathbf{0 . 1 4}$ & $\mathbf{0 . 6 2}$ & $\mathbf{1 . 5 0}$ & $\mathbf{3 2 . 5 0}$ & $\mathbf{6 6 . 5 8}$ \\
\hline
\end{tabular}

The figures having common letter in a column are not significantly at $5 \%$ level by DMRT. S. E. (M) = Standard error of mean, $\mathrm{CV}=\mathrm{Co}$-efficient of variation.

treatment produced the longest length of spike $(9.13 \mathrm{~cm})$. However, depending upon the degree of grain yield of wheat the treatments might be ranked in the order $T_{2}>T_{3}>T_{5}>T_{4}>T_{1}$.

Significantly highest amount of 1000-grain weight $(43.08 \mathrm{~g})$, yield of grain $(2992 \mathrm{~kg} / \mathrm{ha})$ and straw weight $(4342 \mathrm{~kg} / \mathrm{ha})$ of wheat were obtained by applying $\mathrm{T}_{2}$ treatment which was employed with the application of S with NPK. No identical differences were found in 1000-grain weight among all other treatments $\left(\mathrm{T}_{3}, \mathrm{~T}_{4}\right.$ and $\left.\mathrm{T}_{5}\right)$. The significantly second highest yield of grain $(2908 \mathrm{~kg} / \mathrm{ha})$ and straw $\left(\mathrm{T}_{5} 4108\right.$ $\mathrm{kg} / \mathrm{ha}$ and $\mathrm{T}_{3} 4092 \mathrm{~kg} / \mathrm{ha}$ were identically same) were produced in receiving $\mathrm{T}_{3}\left(\mathrm{~T}_{3}\right.$ and $\mathrm{T}_{5}$ treatments were identically same) treatment numerically followed by $\mathrm{T}_{5}(2808 \mathrm{~kg} / \mathrm{ha}$ and $4108 \mathrm{~kg} / \mathrm{ha})$. These are in agreement with those results of Gupta et al. [21] who reported that $S$ application significantly increased wheat yield and yield components. Zhang et al., [22], Prasad [23] and Ali et al., [24] also found similar results in their experiments.

\subsection{Macro Nutrient Content in Wheat Grain and Straw}

\subsubsection{Nitrogen (Primary Nutrient) Content in Grain and Straw of Wheat}

The concentration of $\mathrm{N}$ in the grain and straw were significantly influenced by different treatments as shown in Table 2. Nitrogen content in grain of wheat ranged from $1.190 \%\left(\mathrm{~T}_{1}\right.$ control) to $1.310 \%,\left(\mathrm{~T}_{2}\right)$ and $0.230 \%\left(\mathrm{~T}_{1}\right)$ to $0.260 \%\left(\mathrm{~T}_{2}\right)$ in straw. The highest content in both cases (in grain-1.310\%, and straw- $0.260 \%)$ were obtained from $\mathrm{T}_{2}(\mathrm{NPK}+\mathrm{S})$ treatment which was identically similar to $\mathrm{T}_{4} 1.280 \%$ $(\mathrm{NPK}+\mathrm{S}+\mathrm{Mg}+\mathrm{Zn})$ and $\mathrm{T}_{5} 1.300 \%(\mathrm{NPK}+\mathrm{S}+\mathrm{Mg}+\mathrm{Zn}+\mathrm{B})$ for grain, and $\mathrm{T}_{4} 0.260 \%(\mathrm{NPK}+\mathrm{S}+\mathrm{Mg}+$ $\mathrm{Zn})$ for straw. The lowest concentration of $\mathrm{N}$ for both parameters was found in control $\left(\mathrm{T}_{1}\right)$ treatment where only NPK were applied as recommended dose. In $\mathrm{T}_{2}$ treatment, the addition of sulphur with NPK increased the utilization of nitrogen which was supported by Klikocka and Cybulska [25]. These results are also in full agreement with the findings of Grzebisz et al., [26] who found that the efficient application of nitrogen had increased the total uptake of nitrogen.

Mehla et al. [27] reported that the balanced application of NPKZn with and without organic amendments increased the available $\mathrm{N}$ status of soil over their initial status. Nitrogen has positive interactions with $\mathrm{P}$ and $\mathrm{K}$ uptake in crop plants [28]. The increasing $\mathrm{N}$ rate increases uptake of macronutrients like $\mathrm{P}$, $\mathrm{K}, \mathrm{Ca}, \mathrm{Mg}$, and $\mathrm{S}$ provided that these elements are present in sufficient amount in soil. The improvement of the uptake of macronutrients with the addition of $\mathrm{N}$ is reported to be an associated with increase in root 
Table 2. Effect of different treatments on NPK content in grain and straw of wheat.

\begin{tabular}{|c|c|c|c|c|c|c|}
\hline \multirow{2}{*}{ Treatments } & \multicolumn{3}{|c|}{ Grain } & \multicolumn{3}{|c|}{ Straw } \\
\hline & $\mathrm{N}(\%)$ & $\mathrm{P}(\%)$ & $\mathrm{K}(\%)$ & N (\%) & $P(\%)$ & $\mathrm{K}(\%)$ \\
\hline $\mathrm{T}_{1} \mathrm{NPK}$ (Control) & $1.190 \mathrm{c}$ & $0.386 \mathrm{a}$ & $0.790 \mathrm{c}$ & $0.230 \mathrm{~d}$ & $0.043 \mathrm{f}$ & $0.950 \mathrm{~d}$ \\
\hline $\mathrm{T}_{2} \mathrm{NPK}+\mathrm{S}$ & $1.310 \mathrm{abc}$ & $0.405 \mathrm{a}$ & $0.920 \mathrm{a}$ & $0.260 \mathrm{~b}$ & $0.063 \mathrm{~b}$ & $0.990 \mathrm{~cd}$ \\
\hline $\mathrm{T}_{3} \mathrm{NPK}+\mathrm{S}+\mathrm{Mg}$ & $1.230 \mathrm{bc}$ & $0.392 \mathrm{a}$ & $0.860 \mathrm{~b}$ & $0.250 \mathrm{bc}$ & $0.061 \mathrm{bc}$ & $1.090 \mathrm{bc}$ \\
\hline $\mathrm{T}_{4} \mathrm{NPK}+\mathrm{S}+\mathrm{Mg}+\mathrm{Zn}$ & $1.280 \mathrm{abc}$ & $0.388 \mathrm{a}$ & $0.840 \mathrm{bc}$ & $0.260 \mathrm{~b}$ & $0.050 \mathrm{e}$ & $1.080 \mathrm{bc}$ \\
\hline $\mathrm{T}_{5} \mathrm{NPK}+\mathrm{S}+\mathrm{Mg}+\mathrm{Zn}+\mathrm{B}$ & $1.300 \mathrm{abc}$ & $0.393 \mathrm{a}$ & $0.880 \mathrm{ab}$ & $0.240 \mathrm{~cd}$ & $0.070 \mathrm{a}$ & $1.040 \mathrm{~cd}$ \\
\hline CV (\%) & 4.750 & 6.230 & 3.720 & 7.100 & 6.800 & 5.960 \\
\hline S. E. $( \pm)$ & 0.051 & 0.025 & 0.025 & 0.008 & 0.816 & 0.051 \\
\hline
\end{tabular}

The figures having common letters in a column are not statistically significant at 5\% level by DMRT; S. E. $(\mathrm{M})=$ Standard error of mean, $\mathrm{CV}=\mathrm{Co}$-efficient of variation.

hairs, chemical changes in the rhizosphere and physiological changes stimulated by $\mathrm{N}$, which influences transport of these elements [29,30]. Sachdev et al. [31] also observed that grain without N plots had exposed significantly lower contents of $\mathrm{N}$.

\subsubsection{Phosphorus (Primary Nutrient) Content in Grain and Straw of Wheat}

The concentration of $\mathrm{P}$ in wheat grain was not significantly different among all the treatments (Table 2 ), in spite their values were numerically different from each other and those were laid from $0.386 \%$ to $0.405 \%$. Though the treatments did not show any significant variation among them, the content of $\mathrm{P}$ increased with different treatments as compared to the control $\left(\mathrm{T}_{1}\right)$. The highest percentage of $\mathrm{P}(0.405 \%)$ was obtained with the treatment $\mathrm{T}_{2}$ followed by $\mathrm{T}_{5}(0.393 \%), \mathrm{T}_{3}(0.392 \%)$ and $\mathrm{T}_{4}(0.388 \%)$. These results are in accordance with those of Jones et al., [30] who obtained the optimum range of $\mathrm{P}$ content in wheat grain from $0.20 \%-0.40 \%$. In wheat straw, phosphorus content varied from $0.043 \%$ to $0.070 \%$, where the highest percentage was recorded in $\mathrm{T}_{5}(0.070 \%)$ followed by $\mathrm{T}_{2}(0.063 \%)$ and $\mathrm{T}_{3}(0.061 \%)$, which were identically different from each other, and the lowest was found in control $\left(\mathrm{T}_{1}\right)$ treatment.

\subsubsection{Potassium (Primary Nutrient) Content in Grain and Straw of Wheat}

In wheat grain and straw, the concentration of $\mathrm{K}$ was influenced significantly by the combinations of different treatments exposed in Table 2 . The content of potassium varied from $0.790 \%$ to $0.920 \%$ in grain and $0.950 \%$ to $1.090 \%$ in straw. The significantly highest content of $\mathrm{K}$ in grain was observed in $\mathrm{T}_{2}(0.920 \%)$ followed by $\mathrm{T}_{5}(0.880 \%), \mathrm{T}_{3}(0.860 \%)$ and $\mathrm{T}_{4}(0.840 \%)$, and in the case of straw, the highest was recorded in $\mathrm{T}_{3}(1.090 \%)$ treatment. The lowest content of $\mathrm{P}$ was recorded in $\mathrm{T}_{1}$ (control) for both cases $(0.790 \%$ in grain and $0.950 \%$ in straw). These results are supported Jones et al., by [30]. Moreover, the availability of potassium and sulphur in addition to $\mathrm{N}$ and $\mathrm{P}$ in soil is essential for proper growth and crop yield [32].

\subsubsection{Sulphur (Secondary Nutrient) Content in Grain and Straw of Wheat}

The results presented in Table 3 indicate that the application of the combination of different nutrient elements had significant effect on $\mathrm{S}$ concentration in grain and straw of wheat. Sulphur content in grain varied from $0.089 \%$ to $0.108 \%$ and in straw $0.141 \%$ to $0.191 \%$. In the context of grain, the highest $S$ content was recorded $0.108 \%$ in $\mathrm{T}_{2}$ and $\mathrm{T}_{3}$ treatments, though all values receiving from all treatments without control were identically same to each other, however, all these were significantly greater than the control $\mathrm{T}_{1}(0.089 \%)$. On the contrary, the significantly highest content of $\mathrm{S}$ in straw was recorded $0.191 \%$ with the 
Table 3. Effect of different treatments on $\mathrm{S}$ and $\mathrm{Mg}$ content in grain and straw of wheat.

\begin{tabular}{|c|c|c|c|c|}
\hline \multirow{2}{*}{ Treatments } & \multicolumn{2}{|c|}{ Grain } & \multicolumn{2}{|c|}{ Straw } \\
\hline & S (\%) & $\operatorname{Mg}(\%)$ & S (\%) & $\operatorname{Mg}(\%)$ \\
\hline $\mathrm{T}_{1} \mathrm{NPK}$ (Control) & $0.089 \mathrm{~b}$ & $0.182 \mathrm{a}$ & $0.141 \mathrm{e}$ & $0.098 \mathrm{c}$ \\
\hline $\mathrm{T}_{2} \mathrm{NPK}+\mathrm{S}$ & $0.108 \mathrm{a}$ & $0.186 \mathrm{a}$ & $0.165 \mathrm{~d}$ & $0.101 \mathrm{c}$ \\
\hline $\mathrm{T}_{3} \mathrm{NPK}+\mathrm{S}+\mathrm{Mg}$ & $0.108 \mathrm{a}$ & $0.189 \mathrm{a}$ & $0.189 \mathrm{a}$ & $0.102 \mathrm{c}$ \\
\hline $\mathrm{T}_{4} \mathrm{NPK}+\mathrm{S}+\mathrm{Mg}+\mathrm{Zn}$ & $0.105 \mathrm{a}$ & $0.191 \mathrm{a}$ & $0.191 \mathrm{a}$ & $0.111 \mathrm{~b}$ \\
\hline $\mathrm{T}_{5} \mathrm{NPK}+\mathrm{S}+\mathrm{Mg}+\mathrm{Zn}+\mathrm{B}$ & $0.106 \mathrm{a}$ & $0.191 \mathrm{a}$ & $0.178 \mathrm{~b}$ & $0.102 \mathrm{c}$ \\
\hline $\mathrm{CV}(\%)$ & 3.370 & 7.540 & 2.010 & 4.620 \\
\hline S. E. $( \pm)$ & 0.816 & 0.0081 & 0.816 & 0.816 \\
\hline
\end{tabular}

The figures having common letter in a column are not statistically significant at 5\% level by DMRT; S. E. $(\mathrm{M})=$ Standard error of mean, $\mathrm{CV}=$ Co-efficient of variation .

treatment $\mathrm{T}_{4}$ followed by $\mathrm{T}_{3}(0.189 \%), \mathrm{T}_{5}(0.178 \%)$ and $\mathrm{T}_{2}(0.165 \%)$ were statistically greater compare to the lowest value at $0.141 \%$ in $\mathrm{T}_{1}$ (control). Increasing $\mathrm{S}$ nutrient content in grain and straw owing to increased availability of nutrients to the crop as a result of improved soil fertility with higher rates of $\mathrm{S}$ application may also be responsible for higher uptake of nutrients at increased rates of S application. The results are in close conformity with the findings of Singh et al. [33].

\subsubsection{Magnesium (Secondary Nutrient) Content in Grain and Straw of Wheat}

Table 3 indicates that the application of different treatment combinations did not show any significant effect on $\mathrm{Mg}$ content in the grain of wheat. Alternatively, $\mathrm{Mg}$ in wheat straw was significantly affected only with $\mathrm{T}_{4}(0.111 \%)$ treatment combination, and in grain the maximum content of $\mathrm{Mg}(0.191 \%)$ was also found from the same treatment $\left(\mathrm{T}_{4}\right)$. However, very little numerical differences were observed in $\mathrm{Mg}$ content in wheat grain and straw under all treatments where their values were varied from $0.182 \%$ to $0.191 \%$ in grain, and $0.098 \%$ to $0.111 \%$ in straw. The lowest $(0.098 \%)$ was found in control $\left(\mathrm{T}_{1}\right)$ for both parameters. The percentage of $\mathrm{Mg}$ obtained here is consistent with the findings of Jones et al. [30] who displayed the optimum range of $\mathrm{Mg}$ from $0.15 \%-0.50 \%$ in wheat plant. The results for $\mathrm{Mg}$ content in grain and straw of wheat revealed that the treatment combinations composed of recommended doses of different nutrient elements applied in the experiment did not behave synergistically or antagonistically. Trace amount of $\mathrm{Mg}$ was increased in grain and straw when $\mathrm{Mg}$ containing fertilizer (magnesium oxide) was added in all the treatments.

\subsection{Micro Nutrient Concentration in Wheat}

\subsubsection{Zinc Content in Grain and Straw of Wheat}

The results presented in Table 4 indicate that the application of different treatments had significant effect on $\mathrm{Zn}$ concentration in grain and straw of wheat. $\mathrm{Zn}$ content in wheat grain ranged from 26.17 to $34.08 \mathrm{ppm}$, and 10.93 to $23.59 \mathrm{ppm}$ in straw. The highest content of $\mathrm{Zn}$ in grain and straw were $34.08 \mathrm{ppm}$ and $23.59 \mathrm{ppm}$ respectively by receiving the treatment $\mathrm{T}_{5}(\mathrm{NPK}+\mathrm{S}+\mathrm{Mg}+\mathrm{Zn}+\mathrm{B})$ and the lowest were found in $\mathrm{T}_{1}$ (control) treatment in both cases. The obtained content of $\mathrm{Zn}$ from $\mathrm{T}_{5}$ treatment was significantly different from all other treatments. The second highest content was recorded in $\mathrm{T}_{4}$ treatment both in grain $(30.77 \mathrm{ppm})$ and straw $(22.00 \mathrm{ppm})$. The extracted $\mathrm{Zn}$ concentration from $\mathrm{T}_{4}$ in grain was statistically similar to those of $\mathrm{T}_{2}(29.33 \mathrm{ppm})$ and $\mathrm{T}_{3}(28.04 \mathrm{ppm})$ treatments. Regarding straw, the output from 
Table 4. Effect of different treatments on $\mathrm{Zn}$ and $\mathrm{B}$ content in grain and straw of wheat.

\begin{tabular}{ccccc}
\hline \multirow{2}{*}{ Treatments } & \multicolumn{2}{c}{ Grain } & \multicolumn{2}{c}{ Straw } \\
\cline { 2 - 5 } & Zn (ppm) & B (ppm) & Zn (ppm) & B (ppm) \\
\hline $\mathrm{T}_{1} \mathrm{NPK}$ (Control) & $26.17 \mathrm{c}$ & $10.03 \mathrm{e}$ & $10.93 \mathrm{~d}$ & $28.84 \mathrm{c}$ \\
$\mathrm{T}_{2} \mathrm{NPK}+\mathrm{S}$ & $29.33 \mathrm{~b}$ & $11.29 \mathrm{cde}$ & $12.65 \mathrm{bcd}$ & $29.89 \mathrm{bc}$ \\
$\mathrm{T}_{3} \mathrm{NPK}+\mathrm{S}+\mathrm{Mg}$ & $28.04 \mathrm{bc}$ & $11.91 \mathrm{bcd}$ & $14.81 \mathrm{~b}$ & $29.47 \mathrm{bc}$ \\
$\mathrm{T}_{4} \mathrm{NPK}+\mathrm{S}+\mathrm{Mg}+\mathrm{Zn}$ & $30.77 \mathrm{~b}$ & $12.96 \mathrm{~b}$ & $22.00 \mathrm{a}$ & $31.35 \mathrm{~b}$ \\
$\mathrm{~T}_{5} \mathrm{NPK}+\mathrm{S}+\mathrm{Mg}+\mathrm{Zn}+\mathrm{B}$ & $34.08 \mathrm{a}$ & $15.05 \mathrm{a}$ & $23.59 \mathrm{a}$ & $37.41 \mathrm{a}$ \\
$\mathrm{CV}(\%)$ & 5.36 & 2.85 & 7.38 & 4.79 \\
S. E. $( \pm)$ & 1.29 & 1.00 & 0.58 & 0.94 \\
\hline
\end{tabular}

The figures having common letter in a column are not statistically significant at 5\% level by DMRT; S. E. $(\mathrm{M})=$ Standard error of mean, $\mathrm{CV}=\mathrm{Co}$-efficient of variation .

$T_{5}$ was statistically similar with that of $T_{4}$ followed by $T_{3}, T_{2}$ and $T_{1}$. Results exposed that the content of $\mathrm{Zn}$ from every treatment in grain was substantially greater correspondingly than those of straw. However, it was revealed that Zinc content in wheat grain and straw increased by the addition of $\mathrm{Zn}$ disclosed both in the treatments $\mathrm{T}_{4}$ and $\mathrm{T}_{5}$ which is in accordance with those results of Brennan [34]. Wang et al., [35] also reported that in general, the average grain $\mathrm{Zn}$ content in wheat without $\mathrm{Zn}$ fertilizer was $28.96 \mathrm{ppm}$, which increased to $36.61 \mathrm{ppm}$ after $\mathrm{Zn}$ fortification. Our results are fully supported by the findings of their statement. Shi et al., [36] found that higher $\mathrm{N}$ rates had a positive effect on $\mathrm{Zn}$ accumulation in wheat grain.

\subsubsection{Boron Content in Grain and Straw of Wheat}

Table 4 exposes that the application of different treatment combinations with nutrient elements had significant effect on B status in the grain and straw of wheat. The values from the highest to the lowest content of B in straw (37.41 to $28.84 \mathrm{ppm}$ ) were greater than those of grain (15.05 to $10.03 \mathrm{ppm}$ ) of wheat correspondingly. This was inversely related with $\mathrm{Zn}$ extraction in this experiment. The maximum B content were obtained $15.05 \mathrm{ppm}$ from grain and $37.41 \mathrm{ppm}$ from straw in receiving $\mathrm{T}_{5}(\mathrm{NPK}+\mathrm{S}+\mathrm{Mg}+\mathrm{Zn}$ $+\mathrm{B})$ treatment, which was significantly different from all other treatments. The highest content of $\mathrm{B}$ obtained here is in agreement with those of Islam and Jahiruddin [37] found in their experiment on an average of $13.08 \mathrm{ppm} \mathrm{B}$ in wheat grain. The lowest value $10.03 \mathrm{ppm}$ in grain and $28.84 \mathrm{ppm}$ in straw were recorded in $\mathrm{T}_{1}$ (control) treatment those were significantly different from all other treatments. There was no significant difference of $B$ in wheat straw in between the treatments $T_{2}(29.89 \mathrm{ppm})$ and $\mathrm{T}_{3}(29.47 \mathrm{ppm})$. Abedin et al. [38] observed that $\mathrm{N}$ and $\mathrm{B}$ content in grain increased by applying $\mathrm{B}$ to the soil. The overall result evaluated that $\mathrm{B}$ content of wheat grain was higher in micronutrient treatments than those of secondary nutrients [39].

\section{CONCLUSIONS}

The plant height, tillers per hill, 1000-grain weight, yield of grain and straw weight of wheat were significantly influenced by the application with the treatment combinations in the experiment. These parameters were responded significantly by applying the secondary nutrients $\mathrm{S}$ and $\mathrm{Mg}$, and micronutrients $\mathrm{Zn}$ and B to the wheat crop. The grain yield of wheat varied from 2650 to $2992 \mathrm{~kg} / \mathrm{ha}$ and straw from 3583 $4342 \mathrm{~kg} / \mathrm{ha}$. The highest plant height, tillers per hill, amount of 1000-grain weight (43.08 g), yield of grain 
$(2992 \mathrm{~kg} / \mathrm{ha})$ and straw weight $(4342 \mathrm{~kg} / \mathrm{ha})$ of wheat were procured by adapting the treatment $\mathrm{T}_{2}(\mathrm{NPK}+$ S).

The nutrient content $\mathrm{N}, \mathrm{K}, \mathrm{S}, \mathrm{Zn}$ and $\mathrm{B}$ in grain and straw of wheat were significantly influenced by the application of different treatments. In the case of $\mathrm{P}$ and $\mathrm{Mg}$ content the treatments were not affected significantly. In wheat grain, the content of $\mathrm{N}, \mathrm{P}, \mathrm{K}, \mathrm{S}, \mathrm{Mg}, \mathrm{Zn}$ and $\mathrm{B}$ ranged from $1.190 \%$ to $1.310 \% \mathrm{~N}$, $0.386 \%$ to $0.405 \% \mathrm{P}, 0.790 \%$ to $0.920 \% \mathrm{~K}, 0.089 \%$ to $0.108 \% \mathrm{~S}, 0.182 \%$ to $0.191 \% \mathrm{Mg}, 26.17$ to $34.08 \mathrm{ppm}$ $\mathrm{Zn}$ and 10.03 to $15.05 \mathrm{ppm} \mathrm{B}$. Similarly in straw, nutrients content ranged from $0.230 \%$ to $0.260 \% \mathrm{~N}$, $0.043 \%$ to $0.070 \% \mathrm{P}, 0.950 \%$ to $1.090 \% \mathrm{~K}, 0.141 \%$ to $0.191 \% \mathrm{~S}, 0.098 \%$ to $0.111 \% \mathrm{Mg}, 10.93$ to $23.59 \mathrm{ppm}$ $\mathrm{Zn}$ and 28.84 to $37.41 \mathrm{ppm} \mathrm{B}$.

The main finding of this experiment was the application of different treatments composed of secondary nutrients $\mathrm{S}$ and $\mathrm{Mg}$, and micronutrients $\mathrm{Zn}$ and $\mathrm{B}$ influenced different parameters of wheat (BARI Gom 26) production and uptake of different nutrient contents. Among all the treatments, $\mathrm{T}_{2}$ composed of recommended dose of NPK with S significantly increased plant height, tillers/hill, 1000-grain weight, yield of grain and straw, uptake of $\mathrm{N}, \mathrm{P}, \mathrm{K}$ and $\mathrm{S}$ in grain and straw of wheat. Therefore, $\mathrm{T}_{2}$ treatment for broader area in economics context and $\mathrm{T}_{5}$ for micronutrient context could be efficient practice for achieving sustainable yield with maximum nutrient uptake in the "North Eastern Barind Tract" soils of Bangladesh.

\section{CONFLICTS OF INTEREST}

The authors declare no conflicts of interest regarding the publication of this paper.

\section{REFERENCES}

1. BBS (Bangladesh Bureau of Statistics) (2013) Pocked Book, Bangladesh. Stat. Div. Mins. Planning, Govt. People's Repub., Bangladesh, Dhaka.

2. Bhuiyan, N.I. (1994) Crop Production Trends and Need of Sustainability in Agriculture. The Workshop on Integrated Nutrient Management for Sustainable Agriculture, Dhaka, 26-28 June 1994.

3. FRG (2012) Fertilizer Recommendation Guide. Bangladesh Agricultural Research Council, Dhaka.

4. Jahiruddin, M., Bhuiya, Z.H., Hoque, M.S. and Rahman, L. (1981) Effects of Rates and Methods of Zinc Application on Rice. Madras Agricultural Journal, 68, 211-216.

5. Islam, A., Ahmed, F. and Ahmed, Z. (1986) Sulphur Status of Some Soils of Bangladesh and Effect of Applied Sulphur on the Growth and Yield of Rice. In: Proc. Sulphur Agric. Soils, BARC, Dhaka, 351-370.

6. Narimani, H., Rahimi, M.M., Ahmadikhah, A. and Vaezi, B. (2010) Study on the Effects of Foliar Spray of Micronutrient on Yield and Yield Components of Durum Wheat. Archives of Applied Science Research, 2, 168-176.

7. Hussain, S.S. (1990) Sulphur in Bangladesh Agriculture. Sulphur in Agriculture, 14, 25-28.

8. Li, B.Y., Zhou, D.M., Cang, L., Zhang, H.L., Fan, X.H. and Qin, S.W. (2007) Soil Micronutrient Availability to Crops as Affected by Long-Term Inorganic and Organic Fertilizer Applications. Soil and Tillage Research, 96, 166-173. https://doi.org/10.1016/j.still.2007.05.005

9. Jahiruddin, M., Ali, M.S., Hossain, M.A., Ahmed, M.U. and Hoque, M.M. (1995) Effect of Boron on Grain Set, Yield and Some Other Parameters of Wheat Cultivars. Bangladesh Journal of. Agricultural Science, 22, 179-184.

10. Jahiruddin, M. (1993) Combating Floret Sterility of Wheat through Boron Supplement. BAURES Prog., 7, 36-44.

11. Islam, M.R., Rasat, T.M. and Jahiruddin, M. (1997) Direct and Residual Effects of S. Zn and B on Yield and Nutrient Uptake in a Rice Mustard Cropping System. Journal of the Indian Society of Soil Science, 45, 126-129.

12. Mondal, M.H.R., Jahiruddin, M., Rahman, M.M and Hashem, M.A. (1992) An Investigation on Nutrient Requirement of BR-Il Rice Old Brahmaputra Floodplain Soil. Bangladesh Journal of Crop Science, 2, 22-31. 
13. UNDP and FAO (1988) Land Resources Appraisal of Bangladesh for Agricultural Development. Report 2. Agro-Ecological Region of Bangladesh, United Nations Development Programe and Food and Agricultural Organization. 212-221.

14. Page, A.L., Miller, R.H. and Keeney, D.R. (1982) Methods of Soil Analysis Part 2. 2nd Edition, American Society of Agronomy Inc., Madison.

15. Hunter, A.H. (1984) Soil Fertility Analytical Services in Bangladesh. Consultancy Report, BARC, Dhaka.

16. Yoshida, S.D., Forno, A., Cock, J.H. and Gomez, K.A. (1976) Laboratory Manual for Physiological Studies of Rice. 3rd Edition, International Rice Research Institute, Manila, 14-22.

17. Chapman, C.A. and Pratt, P.F. (1964) Methods of Analysis for Soil, Plant and Water. Division of Agricultural Science, University of California, Oakland.

18. Gomez, K.A. and Gomez, A.A. (1984) Statistical Procedures for Agricultural Research. 2nd Edition, John Wiley and Sons, New York, 680.

19. Hossain, A., Sarker, M.A.Z., Hakim, M.A., Islam, M.T. and Ali, M.E. (2011) Effect of Lime, Magnesium and Boron on Wheat (Triticum aestivum L.) and Their Residual Effects on Mungbean (Vigna radiata L.). International Journal of Agricultural Research, Innovation and Technology, 1, 9-15. https://doi.org/10.3329/ijarit.vli1-2.13923

20. Islam, M.A. (1995) A Study on the Competitive Ability of Six Varieties of Wheat with Weeds. MS Thesis, Bangladesh Agricultural University, Bangladesh, 30-33.

21. Gupta, V.K., Kumar, S. and Singh, A.K. (2004) Yield and Quality of Wheat (Triticum aestivum) as Influenced by Sulfur Nutrition and Weed Management. The Indian Journal of Agricultural Sciences, 74, 254-256.

22. Zhang, Z.Y., Sun, K.G., Lu, A.Y. and Zhang, X.B. (1999) Study on the Effect of S Fertilizer Application on Crops and the Balance of $S$ in Soil. The Journal of Agricultural Science, 5, 25-27.

23. Prasad, B. (2003) Effect of Direct and Residual Effects of Different S Fertilizers on Groundnut and Wheat Cropping System on Typic Haplaquent Soils. Plant Nutrition, 26, 997-1008. https://doi.org/10.1081/PLN-120020071

24. Ali, R., Khan, M.J. and Khattak, R.A. (2008) Response of Rice to Different Sources of Sulfur (S) at Various Levels and Its Residual Effect on Wheat in Rice-Wheat Cropping System. Soils as an Environmental System, 27, 131-137.

25. Klikocka, H. and Cybulska, M. (2014) Sulphur and Nitrogen Fertilization of Spring Wheat, Mineral Fertilization of Spring Wheat. LAP Lambert Academic Publishing, Saarbrucken.

26. Grzebisz, W., Przygocka-Cyna, K., Szczepaniak, W., Diatta, J. and Potarzycki, J. (2010) Magnesium as Nutritional Tool of Nitrogen Efficient Management-Plant Production and Environment. Journal of Elementology, $15,771-788$.

27. Mehla, D.S., Singh, J.P., Sekhon, K.S., Sihag, D. and Bhardwaj, K.K. (2008) Long-Term Effects of Inorganic and Organic Inputs on Yield and Soil Fertility in the Rice-Wheat Cropping System in India.

28. Fageria, N.K. (2008) The Use of Nutrients in Crop Plants. CRC Press, New York, 52.

29. Marschner, H. (1995) The Soil-Root Interface (Rhizosphere) in Relation to Mineral Nutrition. In: Mineral Nutrient of Higher Plants, Academic Press, London, 537-595. https://doi.org/10.1016/B978-012473542-2/50017-1

30. Jones Jr., J.B., Wolf, B. and Mills, H.A. (1991) Plant Analysis Handbook: A Practical Sampling, Preparation, Analysis, and Interpretation Guide. Micro-Macro Inc., Athens.

31. Sachdev, M.S., Sachdev, P. and Deb, D.L. (2000) Fate of Fertilizer on Irrigated Wheat and Its Pollution Potential. In: Optimizing Nitrogen Fertilizer Application to Irrigated Wheat. Results of a Coordinated Research Project Organized by the Joint FAO/ IAEA Division on Nuclear Techniques in Food and Agriculture, 1994-1998, Inter- 
national Atomic Energy Agency, Vienna, 129-142.

32. Ponkia, H.P., Vekaria, L.C., Ramani, V.B., Sakrvadia, H.L., Polara, K.B. and Babari, N.B. (2018) Potassium and Sulphur Fertilization of Wheat (Triticum aestivum L.) in Medium Black Calcareous Soils of Saurashtra Region of Gujarat. International Journal of Pure \& Applied Bioscience, 6, 1634-1640. https://doi.org/10.18782/2320-7051.5412

33. Singh, D., Singh, R., Kumar, H. and Kumar, A. (2015) Response of Wheat (Triticum aestivum) to Potassium and Sulphur Application under Residual Effect of Green Leaf Manuring in Rice (Oryza sativa)-Wheat Cropping System. Research in Environment and Life Sciences, 8, 229-232.

34. Bremner, J.M. and Mulvaney, C.S. (1982) Nitrogen-Total. In: Methods of Soil Analysis. Part 2, 2nd Edition, ASA, Madison, 595-623.

35. Wang, M., Kong, F., Liu, R., Fan, Q. and Zhang, X. (2020) Zinc in Wheat Grain, Processing, and Food. Frontiers in Nutrition, 7, 1-10. https://doi.org/10.3389/fnut.2020.00124

36. Shi, R., Zhang, Y., Chen, X., Sun, Q., Zhang, F., Rö, Mheld, V. and Zou, C. (2010) Influence of Long-Term Nitrogen Fertilization on Micronutrient Density in Grain of Winter Wheat (Triticum aestivum L.). Journal of Cereal Science, 51, 165-170. https://doi.org/10.1016/j.jcs.2009.11.008

37. Islam, M.S. and Jahiruddin, M. (2008) Effect of Boron and Sowing Dates on the Nutrients Concentration and Uptake in Wheat (Triticum aestivum). The Agriculturists, 6, 15-22. https://doi.org/10.3329/agric.v6i1.5210

38. Abedin, M.J., Jahiruddin, M., Hoque, M.S., Islam, M.R. and Ahmed, M.U. (1994) Application of Boron for Improving Grain Yield of Wheat. Progressive Agriculture, 5, 75-79.

39. Rerkasem, B. and Loneragan, J.F. (1994) Boron Deficiency in Two Wheat Genotypes in Warm, Subtropical Region. Agronomy Journal, 86, 887-890. https://doi.org/10.2134/agronj1994.00021962008600050024x 